\title{
Enhanced Proliferation, Survival, and Dopaminergic Differentiation of CNS Precursors in Lowered Oxygen
}

\author{
Lorenz Studer, ${ }^{1,3}$ Marie Csete,, ${ }^{2,4}$ Sang-Hun Lee, ${ }^{1,5}$ Nadine Kabbani, ${ }^{1}$ Jean Walikonis,, ${ }^{2}$ Barbara Wold, ${ }^{2}$ and \\ Ron McKay ${ }^{1}$
}

1 Laboratory of Molecular Biology, National Institute of Neurological Disorders and Stroke, National Institutes of Health, Bethesda, Maryland 20892, ${ }^{2}$ Biology Division, California Institute of Technology, Pasadena, California 92215, 3Laboratory of Stem Cell and Tumor Biology, Neurosurgery and Cellular Biochemistry and Biophysics, Sloan Kettering, New York, New York 10021, ${ }^{4}$ Departments of Anesthesiology, and Cell and Developmental Biology, University of Michigan, Ann Arbor, Michigan 48109-0615, and ${ }^{5}$ College of Medicine, Hanyang University, Seoul, 133-791, Korea

\begin{abstract}
Standard cell culture systems impose environmental oxygen $\left(\mathrm{O}_{2}\right)$ levels of $20 \%$, whereas actual tissue $\mathrm{O}_{2}$ levels in both developing and adult brain are an order of magnitude lower. To address whether proliferation and differentiation of CNS precursors in vitro are influenced by the $\mathrm{O}_{2}$ environment, we analyzed embryonic day 12 rat mesencephalic precursor cells in traditional cultures with $20 \% \mathrm{O}_{2}$ and in lowered $\mathrm{O}_{2}(3 \pm 2 \%)$. Proliferation was promoted and apoptosis was reduced when cells were grown in lowered $\mathrm{O}_{2}$, yielding greater numbers of precursors. The differentiation of precursor cells into neurons with specific neurotransmitter phenotypes was also significantly altered. The percentage of neurons of dopaminergic phenotype increased to $56 \%$ in lowered $\mathrm{O}_{2}$ compared with $18 \%$ in $20 \% \mathrm{O}_{2}$. Together, the
\end{abstract}

increases in total cell number and percentage of dopaminergic neurons resulted in a ninefold net increase in dopamine neuron yield. Differential gene expression analysis revealed more abundant messages for FGF8, engrailed-1, and erythropoietin in lowered $\mathrm{O}_{2}$. Erythropoietin supplementation of $20 \% \mathrm{O}_{2}$ cultures partially mimicked increased dopaminergic differentiation characteristic of CNS precursors cultured in lowered $\mathrm{O}_{2}$. These data demonstrate increased proliferation, reduced cell death, and enhanced dopamine neuron generation in lowered $\mathrm{O}_{2}$, making this method an important advance in the ex vivo generation of specific neurons for brain repair.

Key words: CNS precursors; CNS stem cells; dopaminergic neurons; erythropoietin; oxygen; Parkinson's disease
Cultured CNS stem cells have proved useful in defining the pathways that lead to generation of neurons and glia (McKay, 1997). These cells self-renew, and after mitogen withdrawal, differentiate into neurons, astrocytes and oligodendrocytes in predictable proportions (Johe et al., 1996; McKay, 1997). Single extrinsic factors can shift the fate of CNS stem cells toward specific cell lineages (Johe et al., 1996; Panchision et al., 1998). The potential therapeutic application of CNS stem cells in common degenerative and ischemic diseases has become a major focus of research. The generation of dopaminergic neurons from CNS precursors is of special interest given the promising results of fetal cell transplantation in patients with Parkinson's disease (Olanow et al., 1996; Piccini at al., 1999; Freeman et al., 2000).

In clinical settings, gases are appreciated as primary variables in organ survival, with $\mathrm{O}_{2}$ as the critical gas parameter. However, traditional CNS stem cell culture (as well as virtually all other ex vivo cell culture) is performed in nonphysiologically high $\mathrm{O}_{2}$. Standard tissue culture incubator conditions are $5 \% \mathrm{CO}_{2}$ and $95 \%$ air, which exposes cells to a $20 \% \mathrm{O}_{2}$ environment. In mammalian brain, interstitial tissue $\mathrm{O}_{2}$ levels range from $\sim 1$ to $5 \%$ (Table 1 ). We tested the effects of culturing CNS progenitor cells in physiological "lowered" $(3 \pm 2 \%) \mathrm{O}_{2}$, comparing the cultures with those grown in the usual $20 \% \mathrm{O}_{2}$. Our results indicate that oxygen lowered to more physiological levels alters cultured CNS progenitors in important ways; lowered $\mathrm{O}_{2}$ culturing provides marked trophic and proliferative effects on CNS precursors and signifi-

Received May 12, 2000; revised July 6, 2000; accepted July 19, 2000.

This work was supported in part by Defense Advanced Research Projects Agency/ Air Force Office of Scientific Research Grant F49620-98-1-0487 (M.C.) and National Institutes of Health Grants AR40780-8 and AR42671-05 (B.W.). We thank David Panchision for technical support and critical discussions.

L.S. and M.C. contributed equally to this work.

Correspondence should be addressed to Dr. Marie Csete, Anesthesiology Research Laboratories, 1150 West Medical Center Drive, Medical Sciences I, Room 7444, Ann Arbor, MI 48109-0615. E-mail: csete@umich.edu.

Copyright (C) 2000 Society for Neuroscience $0270-6474 / 00 / 207377-07 \$ 15.00 / 0$ cantly changes developmental kinetics and outcome compared with traditional culture conditions. Initial investigation of the molecular basis for these effects reveals selective changes in expression of a subset of functionally interesting genes whose products can partially recapitulate some of the effects of lowered $\mathrm{O}_{2}$ culturing. The shift in precursor-derived neuronal subtype differentiation in lowered $\mathrm{O}_{2}$ cultures suggests a powerful method for large-scale production of specific neurons for brain repair.

\section{MATERIALS AND METHODS}

Animals were housed and treated following National Institutes of Health guidelines. Cells dissected from rat embryonic day 12 (E12) mesencephalon were mechanically dissociated, plated on plastic 24-well plates (Costar, Cambridge, MA) on $12 \mathrm{~mm}$ glass coverslips (Carolina Biological Supply Company, Burlington, NC) precoated with polyornithine-fibronectin, and grown in defined medium with basic fibroblast growth factor (bFGF) (Johe et al., 1996; Studer et al., 1998). After precursor expansion in the presence of bFGF for 4-6 d, bFGF was withdrawn from the medium to promote differentiation. Clonal assays were performed in plastic 48-well plates (Costar). In some studies, recombinant human Epo, recombinant human vascular endothelial growth factor $165\left(\mathrm{VEGF}_{165}\right)$, or recombinant mouse FGF8b, or their neutralizing antibodies (all from R \& D Systems, Minneapolis, MN) were added to cultures at the following concentrations: $0.5 \mathrm{U} / \mathrm{ml}$ Epo, $10 \mu \mathrm{g} / \mathrm{ml}$ Epo neutralizing antibody, $250 \mathrm{ng} / \mathrm{ml} \mathrm{FGF8}$ $5 \mu \mathrm{g} / \mathrm{ml}$ FGF8b neutralizing antibody, $50 \mathrm{ng} / \mathrm{ml} \mathrm{VEGF}$, and $0.5 \mu \mathrm{g} / \mathrm{ml}$ VEGF neutralizing antibody. Dose response for Epo was performed at $0.05,0.5,5$, and $15 \mathrm{U} / \mathrm{ml}$ and at 10 and $100 \mu \mathrm{g} / \mathrm{ml}$ for anti-Epo. Results of all experiments were confirmed by at least two independent culture series. Lowered $\mathrm{O}_{2}$ culture. Cultures were placed in humidified portable isolation chambers (Billups-Rothenberg, Del Mar, CA), flushed daily with a gas mixture of $1 \% \mathrm{O}_{2}$ plus $5 \% \mathrm{CO}_{2}$ plus $94 \% \mathrm{~N}_{2}$. Precise $\mathrm{O}_{2}$ levels in the chamber atmosphere depended on the length of flush $(90 \mathrm{sec}$ at $15 \mathrm{l} / \mathrm{min}$ achieved $6 \% \mathrm{O}_{2}$, and 6 min of flush achieved $1.5 \% \mathrm{O}_{2}$ ), which was not standardized until availability of an $\mathrm{O}_{2}$-sensitive electrode system (OS2000; Animas Corp., Frazer, PA). Thus, "lowered $\mathrm{O}_{2}$ " conditions represent a range of ambient $\mathrm{O}_{2}$ of $3 \pm 2 \%$, which approximates normal brain tissue levels (Table 1). The entire chamber was housed in an incubator to maintain $37^{\circ} \mathrm{C}$ temperature. To minimize oxygen fluctuations at the time of medium changes, media were pre-equilibrated to lowered $\mathrm{O}_{2}$ conditions in separate chambers for several hours (or at $20 \% \mathrm{O}_{2}$ ) in the incubator. 
Table 1. Regional rat brain tissue partial pressures of oxygen measured by microelectrode

Brain area $\% \mathrm{O}_{2}$

Cortex (gray)

$2.5-5.3$

Cortex (white)

$0.8-2.1$

Hypothalamus

$1.4-2.1$

Hippocampus

2.6-3.9

Pons, fornix

$0.1-0.4$

Adapted from Silver and Erecinska, 1988.

Bromodeoxyuridine uptake and terminal deoxynucleotidyl transferasemediated biotinylated UTP nick end labeling analysis. Bromodeoxyuridine (BrdU) $(10 \mu \mathrm{M})$ was added to cultures for exactly $60 \mathrm{~min}$, just before fixation. Anti-BrdU staining (Amersham Pharmacia Biotech, Arlington Heights, IL) and terminal deoxynucleotidyl transferase-mediated biotinylated UTP nick end labeling (TUNEL) reaction (Boehringer Mannheim, Mannheim, Germany) were performed according to the protocol of the manufacturer. TUNEL-positive (TUNEL+) cells were visualized by metal-enhanced DAB reaction (Pierce, Rockford, IL) after peroxidase conversion of the FITC label. Phase contrast was used for counting total number of nuclei in a field. All counts were performed by observers blinded to experimental conditions.

Immunohistochemistry. Cells were fixed in $4 \%$ paraformaldehyde plus $0.15 \%$ picric acid-PBS, and standard immunohistochemical protocols followed. The following primary antibodies were used: for stem cell-progenitor characterization, nestin polyclonal \#130 at 1:500 (Martha Marvin and Ron McKay, National Institutes of Health Bethesda, MD), sialic acidsubstituted form of neuronal cell adhesion molecule (PSA-NCAM), engrailed-1 (En1), and FP4 (all monoclonal at 1:2; provided by Tom Jessell, Developmental Studies Hybridoma Bank, Iowa City, IA); for stem cell differentiation, $\beta$-tubulin type III (Tuj1) monoclonal at 1:500 and polyclonal at 1:500 (both Babco, Richmond, CA), O4 monoclonal at 1:5 (Boehringer Mannheim), galactocerebroside monoclonal at 1:50 (Boehringer Mannheim), and glial fibrillary acidic protein (GFAP) at 1:100 (ICN Biochemicals, Costa Mesa, CA); for neuronal subtype differentiation, tyrosine hydroxylase (TH) polyclonal at 1:200-1:500 (Pel-Freez Biologicals, Rogers, AR) or monoclonal at 1:2000 (Sigma, St. Louis, MO), GABA polyclonal at 1:500 (Sigma), serotonin polyclonal at 1:2000 (Sigma), glutamate at 1:500 (Sigma), and dopamine $\beta$-hydroxy-lase at 1:100 (Protos Biotech Corp.). Appropriate fluorescence-tagged (Jackson ImmunoResearch, West Grove, PA) or biotinylated (Vector Laboratories, Burlingame, CA) secondary antibodies were used for visualization.

Cell counts and statistical procedures. Uniform random sampling procedures were used for cell counts and quantified using the fractionator sampling technique (Gundersen et al., 1988). Data are expressed as mean \pm SEM. Statistical comparisons were made by ANOVA with post hoc Dunnett's test when more than two groups were involved. If data were not normally distributed, a nonparametric test (Mann-Whitney $U$ test) was used to compare lowered with $20 \% \mathrm{O}_{2}$ results.

Reverse-phase HPLC determinations of dopamine content. Culture supernatants of medium, HBSS, and HBSS plus $56 \mathrm{~mm} \mathrm{KCl}$ (for evoked release) were stabilized with orthophosphoric acid and metabisulfite and stored at $-80^{\circ} \mathrm{C}$ until analysis. Stabilization, aluminum adsorption, equipment, and elution of dopamine have been described previously (Studer et al., 1996, 1998). Results were normalized against dopamine standards at varying flow rates and sensitivities.

Western blots. Cell pellets were stored at $-80^{\circ} \mathrm{C}$. Pellet was lysed in 20 mM HEPES, pH 7.6, $20 \%$ glycerol, $10 \mathrm{~mm} \mathrm{NaCl}, 1.5 \mathrm{~mm} \mathrm{MgCl}_{2}, 0.2 \mathrm{~mm}$ EDTA, and $0.1 \%$ Triton X-100, with protease inhibitors (Complete; Boehringer Mannheim), homogenized, and incubated on ice for $1 \mathrm{hr}$. After centrifugation, supernatant protein concentration was assayed by BCA (Pierce). For Western blots, the block was 5\% milk in TBS-Tween 20, primary TH antibody (Pel-Freez Biologicals) was used at 1:500, and secondary was HRP-conjugated goat anti-rabbit (Pierce) at 1:5000. Signal was detected with SuperSignal (Pierce).

Reverse transcription-PCR. Cultures were washed once in PBS before solubilization in Trizol (Life Technologies, Gaithersburg, MD) and then stored at $-80^{\circ} \mathrm{C}$. RNA extraction was performed according to the recommendations of the manufacturer (Life Technologies). Superscript kit (Life Technologies) was used for reverse transcription of $10 \mu \mathrm{g}$ of RNA per condition. PCR conditions were optimized by varying $\mathrm{MgCl}_{2}$ concentration and cycle number to determine linear amplification range. Amplification products were identified by size and confirmed by DNA sequencing. $\mathrm{MgCl}_{2}$ concentrations for $\mathrm{TH}$, sonic hedgehog $(\mathrm{SHH})$, and FGFR3 reactions were $2 \mathrm{~mm}$, and for all others was $1.5 \mathrm{~mm}$. Primer sequences, cycle numbers, and annealing temperatures were as follows: GAPDH, [forward (f)] CTCGTCTCATAGACAAGATGGTGAAG, [reverse (r)] AGACTCCACGACATACTCAGCACC, 28 cycles, $59^{\circ} \mathrm{C}, 305 \mathrm{bp}$; von Hippel Lindau (VHL), (f) CCTCTCAGGTCATCTTCTGCAACC, (r) AGGGATGGCACAAACAGTTCC, 35 cycles, $60^{\circ} \mathrm{C}, 208$ bp; hypoxia inducible factor- $1 \alpha$ (HIF1 $\alpha)$, (f) GCAGCACGATCTCGGCGAAGCAAA, (r)
GCACCATAACAAAGCCATCCAGGG, 30 cycles, $59^{\circ} \mathrm{C}, 235 \mathrm{bp}$; Epo, (f) CGCTCCCCCACGCCTCATTTG, (r) AGCGGCTTGGGTGGCGTCTGGA, 30 cycles, $60^{\circ} \mathrm{C}, 385$ bp; VEGF, (f) GTGCACTGGACCCTGGCTTTACT, (r) CGCCTTGCAACGCGAGTCT-GTGTT, 30 cycles, $60^{\circ} \mathrm{C}, 474 \mathrm{bp}$ (detects VEGF-1, VEGF-2, and VEGF-3); Nurr1, (f) TGAAGAGAGCGGAGAAGGAGATC, $\quad(\mathrm{r})$ TCTGGAGTTAAGAAATCGGAGCTG, 30 cycles, $55^{\circ} \mathrm{C}, 255 \mathrm{bp}$; TH (kindly provided by Vera Vikodem, National Institute of Diabetes and Digestive and Kidney Diseases, Bethesda, MD) 30 cycles, $56^{\circ} \mathrm{C}, 300 \mathrm{bp}$; Ptx3, (f) CGTGCGTGGTTGGTTCAAGAAC, (r) GCGGTGAGAATACAGGTTGTGAAG, 35 cycles, $60^{\circ} \mathrm{C}, 257 \mathrm{bp}$; SHH, (f) GGAAGATCACAAGAAACTCCGAAC, (r) GGATGCGAGCTTTGGATTCATAG, 30 cycles, 59 ${ }^{\circ} \mathrm{C}, 354$ bp; FGF8, (f) CATGTGAGGGACCAGAGCC, (r) GTAGTTGTTCTCCAGCAGGATC, 35 cycles, $60^{\circ} \mathrm{C}, 312 \mathrm{bp}$; En1, (f) TCAAGACTGACTACAGCAACCCC, (r) CTTTGTCCTGAACCGTGGTGGTAG, 30 cycles, $60^{\circ} \mathrm{C}, 381$ bp; FGFR3, (f) ATCCTCGGGAGATGACGAAGAC, (r) GGATGCTGCCAAACTTGTTCTC, 30 cycles, $55^{\circ} \mathrm{C}, 326 \mathrm{bp}$; glial-derived neurotrophic factor, according to Moreau et al. (1998); and BDNF, (f) GTGACAGTATTAGCGAGTGGG, (r) GGGTAGTTCGGCATTGC, 35 cycles, $56^{\circ} \mathrm{C}, 213 \mathrm{bp}$.

\section{RESULTS}

\section{Lowered $\mathrm{O}_{2}$ augments precursor cell yield by affecting cell proliferation and cell death and enhances clonal growth}

In lowered $\mathrm{O}_{2}$, precursors from E12 rat mesencephalon expanded in the presence of bFGF yielded an average twofold to threefold more cells than $20 \% \mathrm{O}_{2}$ cultures over a wide range of plating densities (Fig. 1A). To test whether increased precursor yield in lowered $\mathrm{O}_{2}$ is because of increased proliferation, reduced cell death, or both, the cells were pulsed with BrdU at several time points during expansion or differentiation. Increased BrdU labeling indices were found in precursors grown in lowered $\mathrm{O}_{2}$ when compared with traditional cultures. The BrdU labeling index was increased in precursors both during expansion (in the presence of bFGF) and during differentiation (after mitogen withdrawal) (Fig. $1 B$ ). In addition to increased proliferation in lowered $\mathrm{O}_{2}$ cultures and clones (Fig. 1C), CNS precursors were also less likely to undergo apoptosis than those grown in $20 \% \mathrm{O}_{2}$. The number of TUNEL-positive cells was reduced both during expansion and after bFGF withdrawal (Fig. $1 D$ ). To investigate $\mathrm{O}_{2}$ effects at clonal densities, mesencephalic precursors were first expanded in 20 $\mathrm{ng} / \mathrm{ml}$ bFGF for $6 \mathrm{~d}$ in $20 \% \mathrm{O}_{2}$, passaged and replated at a density of one to five cells per well, and then maintained at either lowered or $20 \% \mathrm{O}_{2}$. After $20 \mathrm{~d}$, bFGF was withdrawn. The efficiency of clone formation was three times higher in lowered $\mathrm{O}_{2}$, and the average clone size increased from $<50$ cells in $20 \% \mathrm{O}_{2}$ to $50-500$ cells in lowered $\mathrm{O}_{2}$ (Fig. $1 C$ ). We conclude that both reduced apoptosis and increased proliferation contribute to greater cell yield in lowered versus $20 \% \mathrm{O}_{2}$.

\section{Cell lineage}

We used a series of molecular markers together with morphological assessment to characterize how lowered $\mathrm{O}_{2}$ culturing affects the choice of differentiation pathways and the kinetics of differentiation. Immunoreactivity for the intermediate filament nestin was used to discriminate CNS stem and progenitor cells from more differentiated progeny (Lendahl et al., 1990). Six days after bFGF withdrawal, the percentage of nestin-positive cells derived from expanded precursors was grossly reduced in lowered $\mathrm{O}_{2}$ compared with $20 \% \mathrm{O}_{2}$ cultures, suggesting that differentiation might have been accelerated in lowered $\mathrm{O}_{2}$. Immunoreactivity to PSA-NCAM, a marker expressed in committed neuronal progenitors (MayerProschel et al., 1997), was also reduced in differentiated lowered $\mathrm{O}_{2}$ cultures. The idea of accelerated progression to a more differentiated phenotype was further supported by the earlier appearance of neuronal and glial markers in lowered $\mathrm{O}_{2}$. The proportion of CNS lineages derived from expanded precursors was determined by immunohistochemical analysis. Neurons were identified by Tuj1, astrocytes were identified by GFAP, and oligodendrocyte precursors were identified by $\mathrm{O} 4$ staining. Five days after bFGF withdrawal, mesencephalic precursors yielded $73 \%$ Tuj1+ cells versus $63 \%$ in $20 \% \mathrm{O}_{2}(n=12, p=0.06)$; no GFAP + cells were detected 
A)

Growth curve

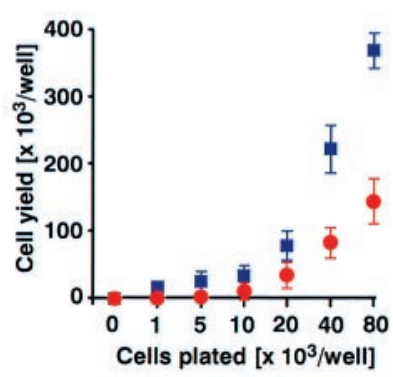

C)

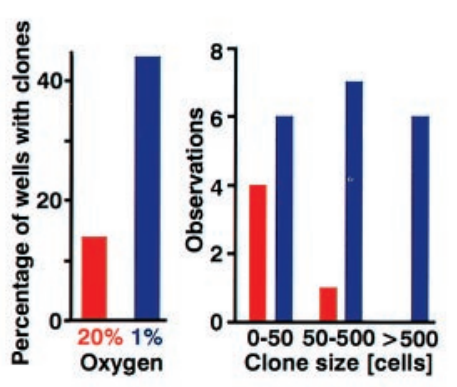

B)

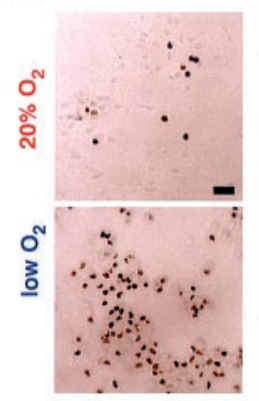

D)

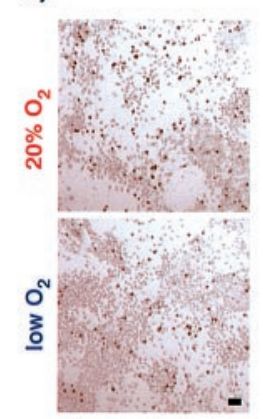

Proliferation assay (BrdU)
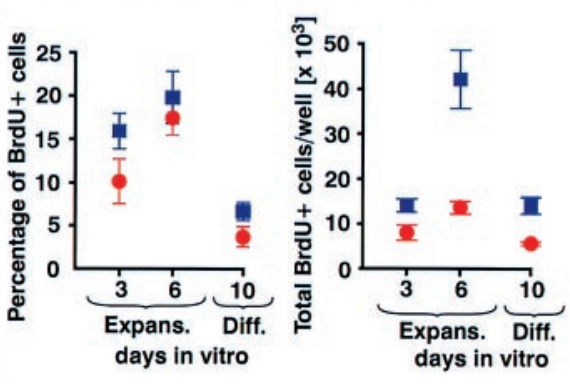

Cell death assay (TUNEL)

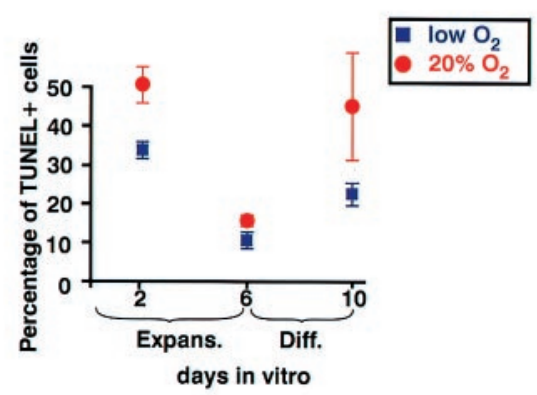

Figure 1. Lowered $\mathrm{O}_{2}$ mediates increased yield of CNS precursors. $A$, Precursor yield across plating densities. CNS precursors derived from the ventral mesencephalon were expanded with bFGF in lowered or $20 \% \mathrm{O}_{2}$, and total cell numbers were assessed after $5 \mathrm{~d}$ of proliferation, when $>90 \%$ of cells are nestin+ precursors. Significantly increased cell numbers were detected at all plating densities in lowered $\mathrm{O}_{2}$ compared with $20 \%$ $\mathrm{O}_{2}$. B, Precursor proliferation. CNS precursors were pulsed with $10 \mu \mathrm{M}$ BrdU for $60 \mathrm{~min}$ immediately before fixation and then stained for BrdU uptake. More $\mathrm{BrdU}+$ cells were seen in lowered $\mathrm{O}_{2}$ cultures during both proliferation and differentiation. Data are presented as mean \pm SEM $(n=40)$. Differences between lowered and $20 \% \mathrm{O}_{2}$ were statistically significant at all time points and for all parameters $(n=8, p<0.05)$, except percentage of BrdU+ cells at day 4 of expansion $(n=8 ; p=0.10)$. Scale bar, 20 $\mu \mathrm{m} . C$, Clonal growth. The yield of clones derived from single precursors was threefold higher in lowered $\mathrm{O}_{2}$ compared with $20 \% \mathrm{O}_{2}$ cultures $(l e f t)$. The majority of clones derived from precursors in lowered $\mathrm{O}_{2}$ cultures contained 50-500 cells, whereas clone size in $20 \% \mathrm{O}_{2}$ cultures was generally $5-50$ cells (right). D, Cell death. Apoptosis was assayed by TUNEL labeling of mesencephalic precursors cultured in either lowered or $20 \% \mathrm{O}_{2}$. Representative TUNEL stains during expanA significant decrease in the percentage of sion $(2$ and $6 \mathrm{~d}$ of culture $)$ and differentiation $(4 \mathrm{~d}$ after bFGF withdrawal) are shown. Scale bar
apoptotic cells in lowered $\mathrm{O}_{2}$ compared with traditional cultures was detected $(n=8 ; p<0.05)$.

in either condition; $1 \%$ were $\mathrm{O} 4+$ versus $0 \%$ in $20 \% \mathrm{O}_{2}(n=12$, $p<0.01)$. The remaining cells were nestin + or did not react with any of the markers tested.

\section{Neuronal subtype differentiation}

We next examined the effect of lowered $\mathrm{O}_{2}$ on neuron subtype differentiation. Compared with traditional cultures, differentiated mesencephalic precursors from lowered $\mathrm{O}_{2}$ cultures displayed a striking increase in both the absolute number and fraction of neurons expressing $\mathrm{TH}$ (Fig. $2 A$ ). In lowered $\mathrm{O}_{2}$, large neuronal clusters were seen in which virtually all neurons were $\mathrm{TH}+$. On average, $56 \%$ of neurons (costained with Tuj1) were $\mathrm{TH}+$ versus $18 \%$ in $20 \% \mathrm{O}_{2}$ cultures $(n=12, p<0.001)$. Increased $\mathrm{TH}$ immunoreactivity in lowered $\mathrm{O}_{2}$ cultures correlated with increased $\mathrm{TH}$ protein content in Western blots (Fig. $2 B$ ). Dopamine production by these neurons was confirmed by reverse-phase HPLC, which showed significantly increased levels of dopamine in lowered versus $20 \% \mathrm{O}_{2}$ cultures (Fig. 2C); conditioned medium (24 hr) showed a fivefold increase in dopamine $(n=5, p<0.01)$, and evoked release was threefold increased $(n=5, p<0.05)$. These results demonstrate that lowered oxygen increases the yield of functional dopaminergic neurons.

Mesencephalic precursors give rise to neurons with several distinct neurotransmitter phenotypes in addition to dopaminergic fate. Interestingly, the percentage of serotonergic neurons was also increased in lowered $\mathrm{O}_{2}, 3.2 \pm 1.2$ versus $1.2 \pm 0.3 \%$ in $20 \% \mathrm{O}_{2}$ $(n=12, p<0.05)$ (Fig. $3 A$ ). On the other hand, the percentage of $\mathrm{GABA}+$ and glutamate + neurons was reduced in lowered $\mathrm{O}_{2}$; only $6.6 \pm 1.8 \%$ of neurons were $\mathrm{GABA}+$ in lowered $\mathrm{O}_{2}$ versus $10.4 \pm$ $1.5 \%$ in $20 \% \mathrm{O}_{2}(n=12, p<0.05)$, and $12.8 \pm 3.8 \%$ of neurons were glutamate + in lowered $\mathrm{O}_{2}$ cultures versus $23.6 \pm 4.0 \%$ in $20 \%$ $\mathrm{O}_{2}(n=12, p<0.01)$. No double labeling of TH with dopamine $\beta$-hydroxylase or TH with GABA was detected (data not shown). These results indicate that $\mathrm{TH}$ immunoreactivity reflected the generation of differentiated dopaminergic neurons but not noradrenergic or adrenergic fates, or the transient developmental expression of TH reported in some GABAergic neurons (Max et al., 1996).
We then examined the effect of lowered oxygen on dopaminergic differentiation as a function of exposure timing, during proliferation versus differentiation. Mesencephalic precursors were expanded for $5 \mathrm{~d}$ in either lowered or $20 \% \mathrm{O}_{2}$. These cultures were then divided for differentiation in either lowered or $20 \% \mathrm{O}_{2}$. Precursors expanded in lowered $\mathrm{O}_{2}$ but differentiated in $20 \% \mathrm{O}_{2}$ resulted in $54 \pm 7 \%$ of all the neurons expressing $\mathrm{TH}$, similar to those maintained in lowered $\mathrm{O}_{2}$ throughout $(58 \pm 7 \%, n=12, p=$ NS) but significantly higher than those maintained throughout in $20 \% \mathrm{O}_{2}(25 \pm 5 \%, n=12, p<0.01)$. Exposure to lowered $\mathrm{O}_{2}$ confined to the differentiation phase did not significantly increase the percentage of neurons expressing $\mathrm{TH}(32 \pm 5 \%, n=12, p=$ NS) compared with cultures maintained in $20 \% \mathrm{O}_{2}$ throughout. These data suggest that important effects of lowered oxygen in promoting dopaminergic differentiation and survival are initiated when the cells are still functionally precursors.

Semiquantitative reverse transcription-PCR was used to assay cultures at various time points for differential expression of genes regulated by oxygen or involved in mediating oxygen responsiveness (Fig. 3B). In addition, we analyzed expression of candidate genes for dopaminergic neuron development (Fig. 3C). As expected, erythropoietin and VEGF RNAs were upregulated in lowered versus $20 \% \mathrm{O}_{2}$ conditions, although with different kinetics (Fig. $3 A$ ). Transcript levels for the tumor suppressor gene VHL and the bHLH-PAS gene hypoxia inducible factor- $1 \alpha$ (HIF1 $\alpha$ ) (Maxwell et al., 1999) did not differ between $\mathrm{O}_{2}$ conditions.

A small increase in TH message was detected from lowered $\mathrm{O}_{2}$ cultures after differentiation compared with $20 \% \mathrm{O}_{2}$. The Ptx 3 homeobox gene, implicated in dopamine neuron development (Smidt et al., 1997), was also expressed at increased levels in lowered $\mathrm{O}_{2}$, confirming that these conditions promoted the specific midbrain dopaminergic phenotype and not just simply upregulated TH expression. Strong evidence links sonic hedgehog (Echelard et al., 1993) and Nurr1 (Saucedo-Cardenas et al., 1998) genes to the differentiation of midbrain dopaminergic neurons, but no $\mathrm{O}_{2}$ dependent changes in their expression were detected. However, 
A)

TH-immunoreactivity

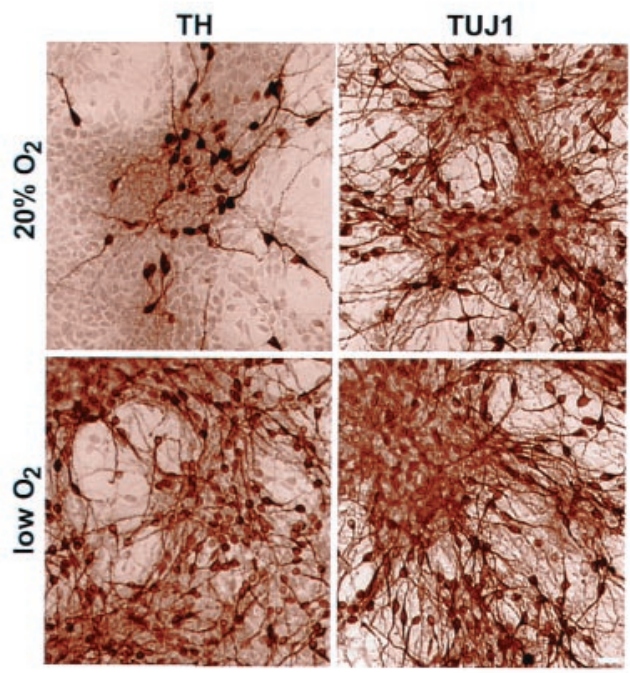

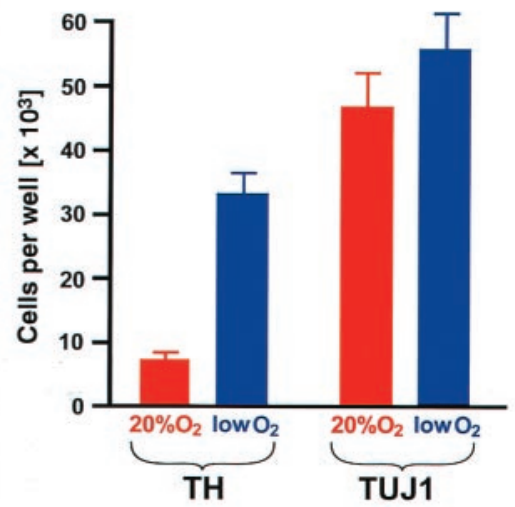

Figure 2. Lowered $\mathrm{O}_{2}$ culturing improves the yield of functional precursor-derived dopaminergic neurons. A, Precursors from E12 mesencephalon were expanded in the presence of bFGF for $5 \mathrm{~d}$, followed by $5 \mathrm{~d}$ of differentiation, and then stained for the neuronal marker Tuj1 and for TH. A large increase in both the total number and percentage of $\mathrm{TH}+$ neurons was detected in lowered $\mathrm{O}_{2}$ compared with $20 \% \mathrm{O}_{2}$ cultures $(p<0.001)$. Scale bar, $20 \mu \mathrm{m}$. B, Western blot analysis revealed significantly more $\mathrm{TH}$ protein in samples from lowered (vs 20\%) $\mathrm{O}_{2}$ cultures. Each lane was loaded with 2.5 $\mu \mathrm{g}$ of total protein. $C$, Reverse-phase HPLC with electrochemical detection was used to quantify dopamine levels in conditioned medium $(24 \mathrm{hr})$ and in buffer with $56 \mathrm{~mm}$ $\mathrm{KCl}$ after 15 min (evoked release). Significantly more dopamine was detected in cultures maintained in lowered $\mathrm{O}_{2}$ compared with those grown in $20 \% \mathrm{O}_{2}(p<0.01$ in conditioned medium; $p<0.05$ for evoked release). Inset shows typical chromatogram for dopamine detection in lowered and $20 \%$ $\mathrm{O}_{2}$ culture media.

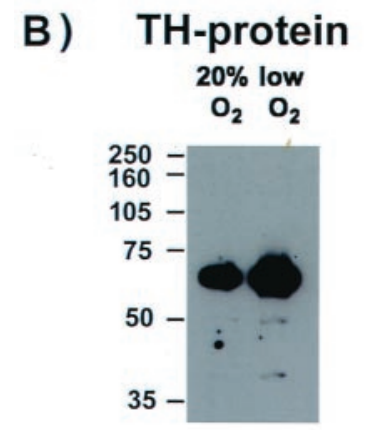

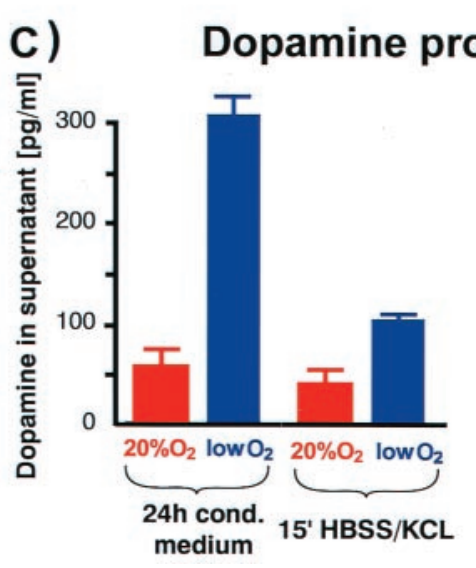

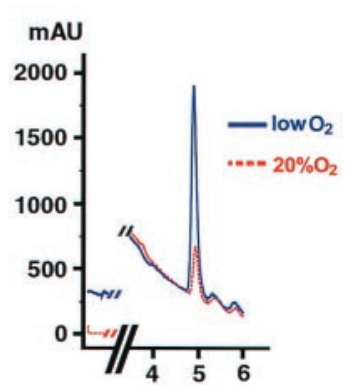

Elution time [min.] engrailed- 1 was upregulated in lowered $\mathrm{O}_{2}$, a finding confirmed at the protein level by immunohistochemistry (Fig. $3 A$ ). FGF8b message was dramatically upregulated in lowered $\mathrm{O}_{2}$ by the end of the expansion phase. Messages for other regulators of dopaminergic differentiation or survival did not differ between $\mathrm{O}_{2}$ conditions.

Based on these results, precursor cells were exposed to recombinant proteins and neutralizing antibodies for FGF8b, VEGF, or Epo in both lowered or $20 \% \mathrm{O}_{2}$ and in the presence of bFGF. VEGF or its neutralizing antibody did not affect the number of dopaminergic neurons generated in the two $\mathrm{O}_{2}$ conditions. FGF8b promoted proliferation in mesencephalic precursors; cells maintained in $20 \% \mathrm{O}_{2}$ increased by $7.5 \pm 1.2$-fold in $5 \mathrm{~d}$ compared with $5.1 \pm 1.0$-fold without FGF8b $(n=6, p<0.05)$. After bFGF withdrawal, continuous FGF8 exposure prolonged precursor proliferation in both $\mathrm{O}_{2}$ conditions and substantially delayed neuronal differentiation, including the generation of $\mathrm{TH}+$ cells. Surprisingly, addition of recombinant human Epo led to a marked dosedependent increase in $\mathrm{TH}+$ cells in $20 \% \mathrm{O}_{2}$ cultures (Fig. 4A,C). Furthermore, addition of Epo neutralizing antibody to both lowered and $20 \% \mathrm{O}_{2}$ cultures dramatically reduced the yield of dopaminergic neurons (Fig. $4 B$ ). These results demonstrate that Epo added to $20 \% \mathrm{O}_{2}$ cultures partially mimics the effects of lowered $\mathrm{O}_{2}$ on dopamine neuron yield. Furthermore, differential oxygendependent gene expression patterns can be used to elucidate pathways important for differentiation and survival of particular neuronal phenotypes.

\section{DISCUSSION}

\section{Lowered oxygen cultures favor proliferation and survival of CNS stem cells}

Standard conditions for the culture of mammalian cells are $37^{\circ} \mathrm{C}$ in a gas atmosphere of $5 \% \mathrm{CO}_{2}$ and $95 \%$ air. Thus, ambient temperature is adjusted to reflect core mammalian body temperature and $\mathrm{CO}_{2}$ is adjusted to reflect approximate venous concentrations, whereas in striking contrast, $\mathrm{O}_{2}$ levels in culture are not adjusted to normal physiological levels. At sea level, unhumidified room air contains $21 \% \mathrm{O}_{2}$, and a $95 \%$ air- $5 \% \mathrm{CO}_{2}$ mixture contains $20 \%$ $\mathrm{O}_{2}$. Alveolar air contains $14 \% \mathrm{O}_{2}$, arterial $\mathrm{O}_{2}$ concentration is $12 \%$, venous $\mathrm{O}_{2}$ levels are $5.3 \%$, and mean tissue $\mathrm{O}_{2}$ concentration is $3 \%$ (Guyton and Hall, 1996). In mammalian brain, interstitial tissue $\mathrm{O}_{2}$ levels range from $\sim 1$ to $5 \%$ (Goda et al., 1997; Liu et al., 1997; Tammela et al., 1997). Data gathered from extensive sampling suggest that mean brain $\mathrm{O}_{2}$ levels in adult rat and fetal sheep are 1.6\% (Koos and Power, 1987; Silver and Erecinska, 1988). Physiological tissue $\mathrm{O}_{2}$ levels in some brain regions are even lower (Table 1).

In this work, we analyze the impact of lowered, more physiological $\mathrm{O}_{2}$ levels on CNS stem cell culture and report four major effects: (1) increased proliferation of progenitors; (2) reduced apoptosis; (3) accelerated progression to differentiated states; and (4) elevated absolute number and proportion of dopaminergic neurons.

Lowered $\mathrm{O}_{2}$ culturing consistently enhanced proliferation of CNS precursors and stem cells. A twofold to fourfold increase in 


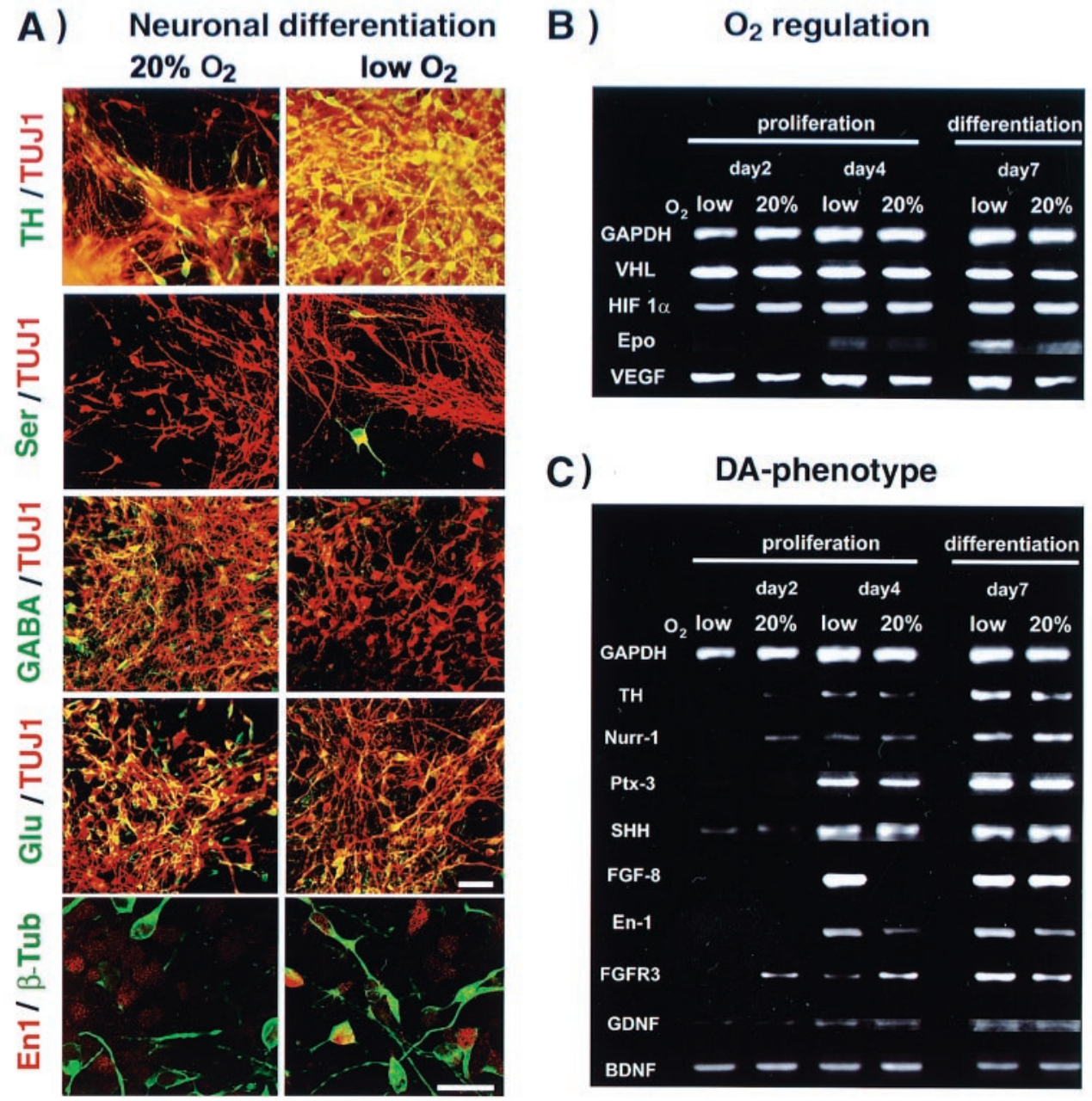

Figure 3. Neuronal subtype differentiation and molecular characterization of mesencephalic precursors in lowered versus $20 \% \mathrm{O}_{2}$. $A$, Double immunocytochemical labeling of neurons (Tuj1+,red) revealed that lowered $\mathrm{O}_{2}$ culturing markedly increased the fractional yield of dopaminergic and serotonergic neuronal subtypes but decreased the fractional yield of GABA+ and glutamate + neurons (all subtype labels, green). The $20 \% \mathrm{O}_{2}$ colony is an example of high GABA expression under these conditions. $\mathrm{TH}$ and GABA were not coexpressed as in some developing neurons in vivo. The percentage of neurons expressing the midbrain transcription factor En1 was increased in lowered $\mathrm{O}_{2}$. Scale bars, $20 \mu \mathrm{m}$. $B, C$, Semiquantitative PCR demonstrates differential gene expression in CNS precursors cultured in lowered or $20 \% \mathrm{O}_{2}$. B, Expression of genes involved in the physiological response to changes in oxygen levels. The expression of HIF1 $\alpha$, VHL, Epo, and VEGF was assessed after 2 or $6 \mathrm{~d}$ of expansion and after $4 \mathrm{~d}$ of differentiation in lowered or $20 \% \mathrm{O}_{2}$. Data are normalized to GAPDH expression. A significant increase in Epo expression was detected in lowered versus $20 \% \mathrm{O}_{2}$ mostly during differentiation, whereas VEGF was upregulated during both expansion and differentiation. No $\mathrm{O}_{2}$-dependent regulation of HIF1 $\alpha$ or VHL messages was observed. $C$, Candidate genes involved in midbrain dopaminergic neuron development were also tested for $\mathrm{O}_{2}$-dependent differential expression. Increased expression of TH and Ptx3 during differentiation confirmed the larger number of functional dopaminergic neurons in lowered $\mathrm{O}_{2}$ cultures (compare with Fig. 2). Significant increases in expression levels of FGF8 and En1 were also detected in lowered $\mathrm{O}_{2}$.

cell number was observed during the proliferation phase when most of the cells are nestin + precursors. The increase in cell number was also maintained after mitogen withdrawal when proliferation overall was vastly reduced. The effects of lowered oxygen were not limited to precursors derived from the ventral mesencephalon. CNS precursors derived from the E14 lateral ganglionic eminences, the anlage of the striatum, and from E14 cortex showed very similar results to those reported here for mesencephalic precursor proliferation, cell death, and clonal growth (data not shown). Although more cells were present in differentiated cultures in lowered $\mathrm{O}_{2}$, our data show that the proportions of neurons and glia were generally similar in the two culture conditions. In neural tissue, there is one supporting, although specialized, precedent for mitogenic activity of lowered $\mathrm{O}_{2}$ in neural crest-derived carotid body chromaffin cells (Nurse and Vollmer, 1997). These dopaminergic glomus cells are functionally specialized $\mathrm{O}_{2}$-sensitive chemoreceptors and so would be expected to be specifically responsive to changes in $\mathrm{O}_{2}$ levels in the carotid artery. Our results show that lowered oxygen enhances the proliferation and survival of CNS stem cells.

We identified two specific growth factors, FGF8 and Epo, as candidates for significant roles in the lowered $\mathrm{O}_{2}$ responses and showed that each can recapitulate part of the lowered $\mathrm{O}_{2}$ phenotype at $20 \% \mathrm{O}_{2}$. In early midbrain development, FGF8 functions as a mitogen (Danelian and McMahon, 1996), but significant mitogenic or trophic effects of FGF8 on CNS stem cell cultures have not been reported. In our study, the increased cell yield from mesencephalic precursors maintained in $20 \% \mathrm{O}_{2}$ and exposed to 250 $\mathrm{ng} / \mathrm{ml}$ FGF8 partly recapitulated the proliferation-trophic effects of lowered $\mathrm{O}_{2}$, with a $30 \%$ increase in total number compared with a $200-400 \%$ increase in lowered $\mathrm{O}_{2}$.
Less apoptosis occurs in CNS stem cells cultured in lowered versus $20 \% \mathrm{O}_{2}$. Among the many possible mechanisms contributing to reduced apoptotic death in lowered oxygen cultures, erythropoietin may act as an anti-apoptotic agent (Quelle et al., 1998) or as an anti-oxidant (Bany-Mohammed et al., 1996). Oxidative activity was not directly measured in our cultures but may contribute to apoptosis in high-oxygen conditions (Zaman et al., 1999). In addition, oxidative stress and decreased ability to respond to oxidative stress are thought to contribute to the pathophysiology of Parkinson's disease (Olanow and Tatton, 1999).

\section{Dopaminergic commitment and differentiation}

For several years, the midbrain has been studied as a model for neuron subtype specification (Ericson et al., 1995; Hynes et al., 1995; Wang et al., 1995; Ye et al., 1998) (for review, see Hynes and Rosenthal, 1999). Under optimal conditions, mesencephalic precursors have been reported to yield neurons in which $24 \%$ are dopaminergic, a markedly improved yield historically (Studer et al., 1998). Lowered oxygen here led not only to higher total cell numbers but also increased the percentage of dopaminergic neurons to a remarkable $56 \%$. The percentage of serotonergic neurons, another ventral neuronal phenotype (Yamada et al., 1991; Hynes et al., 1995; Ye et al., 1998), was also increased in lowered oxygen. In contrast, the fractional yields of GABAergic and glutamatergic neurons were reduced. The lowered oxygen conditions were most effective in generating dopaminergic neurons during the phase of precursor cell expansion. These results suggest that lowered oxygen conditions enhance the production of ventral fates by a mechanism that acts before neuronal differentiation.

Transcript levels of FGF8 and En1, known mediators of midbrain dopaminergic neuron development (Simone et al., 1998; Ye 


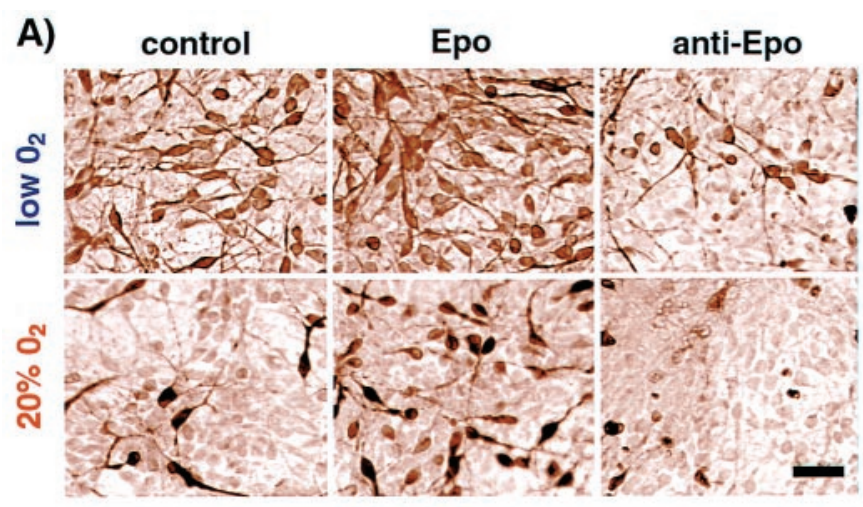

B)

C)
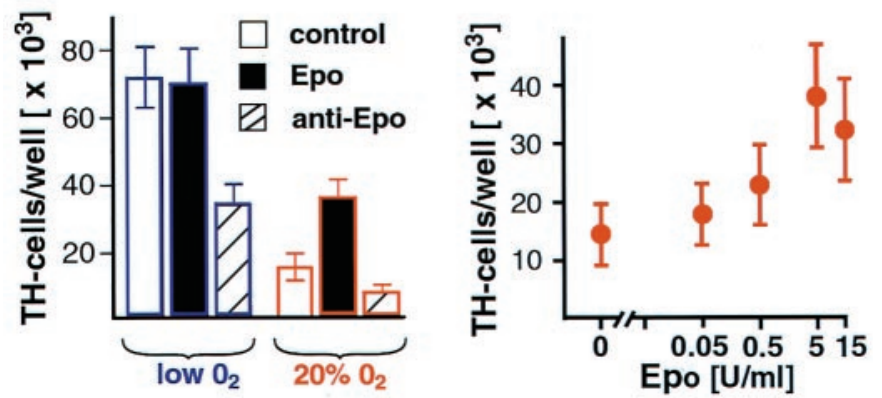

Figure 4. Epo mimics the lowered $\mathrm{O}_{2}$ effect on dopaminergic differentiation. $A$, Representative images of $\mathrm{TH}+$ cells grown in the presence or absence of Epo and anti-Epo antibody and in lowered or $20 \% \mathrm{O}_{2}$ conditions. All reagents were added to E12 mesencephalic precursor cultures throughout cell expansion and differentiation (10 d total) in lowered or $20 \%$ $\mathrm{O}_{2}$. Epo supplementation significantly increased $\mathrm{TH}+$ cell numbers in $20 \%$ $\mathrm{O}_{2}$ cultures $(n=6 ; p<0.05)$. Epo neutralizing antibody decreased $\mathrm{TH}+$ cell numbers in both lowered $\mathrm{O}_{2}(n=6 ; p<0.01)$ and $20 \% \mathrm{O}_{2}$ cultures $(n=$ $6 ; p<0.05)$. Scale bar, $20 \mu \mathrm{m}$. B, Effects of Epo and anti-Epo blocking antibody on dopamine neuron yield. $C$, Epo positively influences dopaminergic neuron yield in $20 \% \mathrm{O}_{2}$ in a dose-dependent manner.

et al., 1998; Shamim et al., 1999), were upregulated in lowered versus $20 \% \mathrm{O}_{2}$ cultures. FGF8 has also been implicated in the commitment of serotonergic neurons (Ye et al., 1998). These findings are consistent with a role for FGF8 in the expansion of dopaminergic and serotonergic neuronal subtypes seen in lowered $\mathrm{O}_{2}$ cultures. However, addition of FGF8 to $20 \% \mathrm{O}_{2}$ cultures or neutralization of FGF8 in lowered $\mathrm{O}_{2}$ cultures did not reproduce the $\mathrm{O}_{2}$-dependent neuronal subtype differentiation patterns. The secreted morphogen $\mathrm{SHH}$ induces dopaminergic neuron differentiation in explants of the early neural plate (Hynes et al., 1995; Wang et al., 1995; Ye et al., 1998). Purified sonic hedgehog (10 $\mathrm{ng} / \mathrm{ml}$ to $1 \mu \mathrm{g} / \mathrm{ml}$ ) had no effect on expanded mesencephalic precursors under both oxygen conditions (data not shown).

Engrailed-1 mRNA and protein levels were increased in lowered oxygen. Engrailed-1 is thought to act in a pathway with pax2, wnt-1, and FGF8 to regulate the fate of midbrain neurons (Wurst et al., 1994; Danelian and McMahon, 1996; Joyner, 1996; Simone et al., 1998). The FGF8 gene contains a binding site for engrailed (Gemel et al., 1999). In addition, we found that the FGF8 5'-UTR sequence (GenBank accession number AF065607) contains a nine base sequence (CCTCCCTCA), which may be involved in oxygen responsiveness in VEGF and Epo regulatory elements (Scandurro and Beckman, 1998). We have not yet determined whether En1 acts as a direct upstream regulator of FGF8 in our lowered $\mathrm{O}_{2}$ cultures or whether they act independently. Nonetheless, the prominent expression of En1 in young neurons (Fig. 3) suggests it may be a good candidate for regulating neuronal subtype differentiation.

Epo levels are known to be regulated by oxygen in the erythropoietic system. Epo and its receptor are expressed in brain from early development through adulthood (Juul et al., 1999), but no specific role for Epo in CNS development has been described. In the adult CNS, however, Epo has received attention as a neuroprotective agent (Sakanaka et al., 1998), and Epo treatment of PC12 cells has been demonstrated to increase intracellular monoamine levels (Masuda et al., 1993). Here we showed that, at 20\% $\mathrm{O}_{2}$, Epo can mimic part of the lowered $\mathrm{O}_{2}$ effect of dopaminergic differentiation and survival. Increases in yield of dopaminergic neurons in $20 \% \mathrm{O}_{2}$ cultures were dose-dependent, but no additional increase in yield was mediated by Epo in lowered oxygen, suggesting that the Epo levels in lowered $\mathrm{O}_{2}$ were at maximal functional levels for this response. Of note, the full effect of lowered $\mathrm{O}_{2}$ on dopaminergic yield could not be recapitulated by Epo, suggesting that additional factors are involved in this $\mathrm{O}_{2}$ mediated outcome. Nonetheless, the finding that Epo alters the differentiation patterns of expanded CNS precursors is novel and identifies Epo as a component of increased dopaminergic neuron yield in lowered oxygen conditions.

A recent report demonstrated increased dopamine content after differentiated dopaminergic mesencephalic neurons were exposed to anoxic $\left(\mathrm{O} \% \mathrm{O}_{2}\right)$ conditions (Gross et al., 1999). Another study described a relative increase in TH-expressing neurons in primary neuronal cultures from E14 rats after exposure to $5 \% \mathrm{O}_{2}$ (Colton et al., 1995). It is also known that hypoxic conditions favor expression of the TH gene (Czyzyk-Krzeska et al., 1994; Paulding and Czyzyk-Krzeska, 1999). However, to our knowledge, this is the first report that lowered $\mathrm{O}_{2}$ conditions support CNS stem cells during the expansion phase and enhance the production of ventral neuronal subtypes.

Overall, our results suggest that $\mathrm{O}_{2}$ levels much lower than those traditionally used in culture allow for improved precursor cell proliferation and provide a powerful tool for the generation of specific neuron types. In particular, lowered $\mathrm{O}_{2}$ culturing has the practical effect of contributing to more efficient production of dopaminergic neurons for potential transplantation therapies. Furthermore, the effects of lowered, more physiological $\mathrm{O}_{2}$ on cell cultures are not limited to the CNS and extend to the peripheral nervous system (Morrison et al., 2000) and to non-neuronal tissues (M. Csete and B. Wold, unpublished observations).

\section{REFERENCES}

Bany-Mohammed FM, Slivka S, Hallman M (1996) Recombinant human erythropoietin: possible role as an antioxidant in premature rabbits. Pediatr Res 40:381-387.

Colton DA, Pagan F, Snell J, Colton JS, Cummins A, Gilbert DL (1995) Protection from oxidation enhances the survival of cultured mesencephalic neurons. Exp Neurol 132:54-61.

Czyzyk-Krzeska MF, Furnari BA, Lawson EE, Millhorn DE (1994) Hypoxia increases rate of transcription and stability of tyrosine hydroxylase mRNA in pheochromocytoma (PC12) cells. J Biol Chem 269:760-764.

Danelian PS, McMahon AP (1996) Engrailed-1 as a target of the Wnt-1 signalling pathway in vertebrate midbrain development. Nature 383:332-334.

Echelard Y, Epstein DJ, St-Jacques B, Shen L, Mahler J, McMahon JA, McMahon AP (1993) Sonic hedgehog, a member of a family of putative signaling molecules, is implicated in the regulation of CNS polarity. Cell 75:1417-1430.

Ericson J, Muhr J, Placzek M, Lints T, Jessell TM, Edlund T (1995) Sonic hedgehog induces the differentiation of ventral forebrain neurons: a common signal for ventral patterning within the neural tube. Cell 81:747-756.

Freeman TB, Vawter DE, Leaverton PE, Godbold JH, Hauser RA, Goetz CG, Olanow CW (2000) Use of placebo surgery in controlled trials of a cellular-based therapy for Parkinson's disease. N Engl J Med 341:988-992.

Gemel J, Jacobsen C, MacArthur CA (1999) Fibroblast growth factor-8 expression is regulated by intronic engrailed and Pbx1-binding sites. J Biol Chem 274:6020-6026.

Goda F, O'Hara JA, Liu KJ, Rhodes ES, Dunn JF, Swartz HJ (1997) Comparisons of measurements of $\mathrm{pO} 2$ in tissue in vivo by EPR oximetry and microelectrodes. Adv Exp Med Biol 411:543-549.

Gross J, Ungethum U, Andreeva N, Heldt J, Gao J, Marschhausen G, Altmann T, Muller I, Husemann B, Andersson K (1999) Hypoxia during early developmental period induces long-term changes in the dopamine content and release in a mesencephalic cell culture. Neuroscience 92:699-704.

Gundersen HJG, Bendtsen TF, Korbo L, Marcussen N, Moller A, Nielsen K, Nyengaard JR, Pakkenberg B, Soerensen FB, Vesterby A, West MJ (1988) Some new, simple and efficient stereological methods and their use in pathological research and diagnosis. APMIS 96:379-394. 
Guyton AC, Hall JE (1996) Textbook of medical physiology. Philadelphia: Saunders.

Hynes M, Rosenthal A (1999) Specification of dopaminergic and serotonergic neurons in the vertebrate CNS. Curr Opin Neurobiol 9:26-36.

Hynes M, Poulsen K, Tessier-Lavigne M, Rosenthal A (1995) Control of neuronal diversity by the floor plate: contact-mediated induction of midbrain dopaminergic neurons. Cell 80:95-101.

Johe KK, Hazel TG, Muller T, Dugich-Djordjevic MM, McKay RD (1996) Single factors direct the differentiation of stem cells from the fetal and adult central nervous system. Genes Dev 10:3129-3140.

Joyner AL (1996) Engrailed, Wnt, and Pax genes regulate midbrainhindbrain development. Trends Genet 12:15-20.

Juul SE, Yachnis AT, Rojiani AM, Christensen RD (1999) Immunohistochemical localization of erythropoietin and its receptor in the developing human brain. Pediatr Dev Pathol 2:148-158.

Koos BJ, Power GG (1987) Predict fetal brain $\mathrm{PO}_{2}$ during hypoxaemia and anemia in sheep. J Dev Physiol 9:517-526.

Lendahl U, Zimmerman LB, McKay RD (1990) CNS stem cells express a new class of intermediate filament protein. Cell 60:585-595.

Liu KJ, Hoopes PJ, Rolett EL, Beerle BJ, Azzawi A, Goda F, Dunn JF, Swartz HM (1997) Effect of anesthesia on cerebral tissue oxygen and cardiopulmonary parameters in rats. Adv Exp Med Biol 411:33-39.

Masuda S, Nagao M, Takahata K, Konishi Y, Gallyas Jr F, Tabira T, Sasaki R (1993) Functional erythropoietin receptors of cells with neural characteristics: comparison with receptor properties of erythroid cells. J Biol Chem 268:11208-11216.

Max SR, Bossio A, Iacovitti L (1996) Co-expression of tyrosine hydroxylase and glutamic acid decarboxylase in dopamine differentiation factortreated striatal neurons in culture. Dev Brain Res 91:140-142.

Maxwell PH, Wiesener MS, Chang GW, Clifford CS, Vaux EC, Cockman ME, Wykoff CC, Pugh CW, Maher ER, Ratcliffe PJ (1999) The tumour suppressor protein VHL targets hypoxia-inducible factors for oxygendependent proteolysis. Nature 399:271-275.

Mayer-Proschel M, Kalyani AJ, Mujtaba T, Rao MS (1997) Isolation of lineage-restricted neuronal precursors from multipotent neuroepithelial stem cells. Neuron 19:773-785.

McKay RD (1997) Stem cells in the central nervous system. Science 276:66-71.

Moreau E, Vilar J, Lelievre-Pegorier M, Merlet-Benichou C, Gilbert T (1998) Regulation of c-ret expression by retinoic acid in rat metanephros: implication in nephron mass control. Am J Physiol 44:F938-F945.

Morrison SJ, Csete M, Groves AK, Melega W, Wold B, Anderson DJ (2000) Culture in reduced levels of oxygen promotes clonogenic sympathoadrenal differentiation by isolated neural crest stem cells. J Neurosci 20:7370-7376.

Nurse CA, Vollmer C (1997) Role of basic FGF and oxygen in control of proliferation, survival, and neuronal differentiation in carotid body chromaffin cells. Dev Biol 184:197-206.

Olanow CW, Tatton WG (1999) Etiology and pathogenesis of Parkinson's disease. Annu Rev Neurosci 22:123-144.

Olanow CW, Kordower JH, Freeman TB (1996) Fetal nigral transplantation as a therapy for Parkinson's disease. Trends Neurosci 19:102-109.

Panchision D, Hazel T, McKay R (1998) Plasticity and stem cells in the vertebrate nervous system. Curr Opin Cell Biol 10:727-733.

Paulding WR, Czyzyk-Krzeska MF (1999) Regulation of tyrosine hydroxylase mRNA stability by protein binding, pyrimidine-rich sequence in the $3^{\prime}$ untranslated region. J Biol Chem 274:2532-2538.
Quelle FW, Wang J, Feng J, Wang D, Cleveland JL, Ihle JN, Zambetti GP (1998) Cytokine rescue of p53-dependent apoptosis and cell cycle arrest is mediated by distinct Jak kinase signaling pathways. Genes Dev 12:1099-1107.

Sakanaka M, Wen TC, Matsuda S, Masuda S, Morishita E, Nagao M, Sasaki $\mathrm{R}$ (1998) In vivo evidence that erythropoietin protects neurons from ischemic damage. Proc Natl Acad Sci USA 95:4635-4640.

Saucedo-Cardenas O, Quintana-Hau JD, Le WD, Smidt MP, Cox JJ, De Mayo F, Burbach JP, Conneely OM (1998) Nurr1 is essential for the induction of the dopaminergic phenotype and the survival of ventral mesencephalic late dopaminergic precursor neurons. Proc Natl Acad Sci USA 95:4013-4018.

Scandurro AB, Beckman BS (1998) Common proteins bind mRNAs encoding erythropoietin, tyrosine hydroxylase, and vascular endothelial growth factor. Biochem Biophys Res Commun 246:436-440.

Shamim $\mathrm{H}$, Mahmood $\mathrm{R}$, Logan $\mathrm{C}$, Doherty $\mathrm{P}$, Lumsden A, Mason I (1999) Sequential roles for Fgf4, En1 and Fgf8 in specification and regionalisation of the midbrain. Development 126:945-959.

Silver I, Erecinska M (1988) Oxygen and ion concentrations in normoxic and hypoxic brain cells. Adv Exp Med Biol 454:7-16.

Simone HH, Saueressig H, Wurst W, Goulding MG, O'Leary DD (1998) En-1 and En-2 control the fate of the dopaminergic neurons in the substantia nigra and ventral tegmentum. Eur J Neurosci 10:389-399.

Smidt MP, van Schaick HS, Lanctot C, Tremblay JJ, Cox JJ, van der Kleij AA, Wolterink G, Drouin J, Burbach JP (1997) A homeodomain gene Ptx 3 has highly restricted brain expression in mesencephalic dopaminergic neurons. Proc Natl Acad Sci USA 94:13305-13310.

Studer L, Psylla M, Buhler B, Evtouchenko L, Vouga CM, Leenders KL, Seiler RW, Spenger C (1996) Non-invasive dopamine determination by reversed phase HPLC in the medium of free-floating roller tube cultures of rat fetal ventral mesencephalon. A tool to assess dopaminergic tissue prior to grafting. Brain Res Bull 41:143-150.

Studer L, Tabar V, McKay R (1998) Transplantation of expanded mesencephalic precursors leads to recovery in parkinsonian rats. Nat Neurosci 1:290-295.

Tammela O, Song D, Olano M, Delivoria-Papadopoulos M, Wilson DF, Pastuszko A (1997) Response of cortical oxygen and striatal extracellular dopamine to metabolic acidosis in newborn piglets. Adv Exp Med Biol 411:103-111.

Wang MA, Jin P, Bumcrot DA, Marigo V, McMahon AP, Wang EA, Woolf T, Pang K (1995) Induction of dopaminergic neuron phenotype in the midbrain by Sonic hedgehog protein. Nat Med 1:1184-1188.

Wurst W, Auerbach AB, Joyner AL (1994) Multiple developmental defects in Engrailed-1 mutant mice: an early mid-hindbrain deletion and patterning defects in forelimbs and sternum. Development 120:2065-2075.

Yamada T, Placzek M, Tanaka H, Dodd J, Jessell TM (1991) Control of cell pattern in the developing nervous system: polarizing activity of the floor plate and notochord. Cell 64:635-647.

Ye W, Shimamura K, Rubenstein JL, Hynes MA, Rosenthal A (1998) FGF and Shh signals control dopaminergic and serotonergic cell fate in the anterior neural plate. Cell 93:755-766.

Zaman K, Ryu H, Hall D, O'Donovan K, Lin KI, Miller MP, Marquis JC, Baraban JM, Semenza GL, Ratan RR (1999) Protection from oxidative stress-induced apoptosis in cortical neuronal cultures by iron chelators is associated with enhanced DNA binding of hypoxia-inducible factor- 1 and ATF-1/CREB and increased expression of glycolytic enzymes, p21 (waf1/ cip1), and erythropoietin. J Neurosci 19:9821-9830. 